\title{
SPADELLA CEPHALOPTERA FORMA ANGULATA RAISED TO THE RANK OF SPECIES
}

$\operatorname{AUTHOR(S):~}$

Tokioka, Takasi; PATHANSALI, D.

\section{CITATION:}

Tokioka, Takasi ...[et al]. SPADELLA CEPHALOPTERA FORMA ANGULATA RAISED TO THE RANK OF SPECIES. PUBLICATIONS OF THE SETO MARINE BIOLOGICAL LABORATORY 1964, 12(2): 145-148

\section{ISSUE DATE:}

1964-10-15

URL:

http://hdl.handle.net/2433/175361

RIGHT: 


\title{
SPADELLA CEPHALOPTERA FORMA ANGULATA RAISED TO THE RANK OF SPECIES
}

\author{
TAKASI TOKIOKA \\ Seto Marine Biological Laboratory \\ and \\ D. PATHANSALI \\ Fisheries Laboratory, Glugor, Penang \\ With Plate $V$
}

In the autumn last year three specimens of Spadella were found in the plankton collection made by the junior author in the coastal waters of Malay. These specimens resemble most closely Spadella cephaloptera forma angulata reported by the senior author from Nanao Bay near the middle of the Japan Sea coast of Honsyû Island, Japan. Two of the specimens were sent to the senior author, and they were identified decidedly by him as $S$. cephaloptera $\mathrm{f}$. angulata. This form was described on five, $2.5-3.0 \mathrm{~mm}$ specimens, characterized by having a pair of lateral fins extending onto the posterior part of the trunk and a pair of angulated seminal vesicles. The Malay specimens have lateral fins extending onto the trunk and the seminal vesicle foreshows a hook-shaped prominence in the most expanded state, though no typically angulated vesicle was found on any specimen. Moreover the Malay and Japanese specimens coincide with each other in that they are devoid of the prominent cement gland at the external opening of the seminal receptacle, which is easily discerned in $S$. cephaloptera. Now, it is very noteworthy that a certain form of Spadella, separable from S. cephaloptera by the lateral fin extending onto the trunk and by the absence of the cement gland at the female genital opening, has been taken at two different localities far apart from each other and in a significant number, up to eight in total, without any intermediate forms having been found between this form and $S$. cephaloptera. This appears to us to show that the peculiar form here stated is neither a phenotype nor a genotype of $S$. cephaloptera, but is a distinct species. Thus we propose here to raise S. cephaloptera f. angulata to the rank of species. The description of the Malay specimens to supplement the original one made in 1951 follows.

Publ. Seto Mar. Biol. Lab., XII (2), 1964. (Article 9) 
Before closing the introductory note we wish to thank the Director of Fisheries, Federation of Malaysia, for his kindness in allowing us to examine the specimens and for permission to publish the present note.

\section{Spadella angulata TokIOKA}

S. cephaloptera f. angulata TokıokA, T. (1951): p. 18, text-fig. 12.

The total body length including the tail fin is 2.50 to $4,18 \mathrm{~mm}$, the tail segment, including the tail fin, is 51.2 to $57.9 \%$ of the total body length. The body is a little more slender than $S$. cephaloptera and it resembles Pterosagitta with the collarette wholly removed; it is broadest at the region of the trunktail septum. The collarette is well developed at the neck, but it soon diminishes in thickness and runs far posteriorly to the seminal vesicle, with several small swellings at the base of respective tangoreceptors situated between neck end the anterior end of the lateral fin. The lateral fin begins in the posterior part of the trunk and reaches posteriorly to the seminal vesicle, but in no specimen does it continue to the tail fin, going round the vesicle as in S. cephaloptera or Krohnitta pacifica. It is broadest near the middle of the range, between septum and vesicle, and the anterior portion lying along the trunk is 16.7 to $23.6 \%$ of the lateral fin length. Rayless zone is wholly absent. The tail fin is spatulate. The corona ciliata is oval, transversely elongated and with a forward projection near the middle (fig. B). This appearance of corona is not unique to this species as it is also seen on some fully grown up individuals of $S$. cephaloptera and in some schizoptera-type species of Spadella. The size of the ventral ganglion is relatively large; the ganglion length is approximately one third of the trunk length. The eye pigment is roundish in superficial outline.

Hooks are 8-9, enterior teeth $3-4$, posterior teeth are missing in all specimens.

\begin{tabular}{c|c|c|c|c|c}
\hline \hline $\begin{array}{c}\text { Total length } \\
\text { in mm. }\end{array}$ & $\begin{array}{c}\text { Length of tail } \\
\text { segment as } \%\end{array}$ & Hooks & $\begin{array}{c}\text { Anterior } \\
\text { teeth }\end{array}$ & $\begin{array}{c}\text { Fin length } \\
\text { as \% }\end{array}$ & $\begin{array}{c}\text { Fin above } \\
\text { septum** }\end{array}$ \\
\hline $2.5 *$ & 51.2 & $8-9$ & - & 32.8 & 19.5 \\
3.0 & 53.6 & $8-8$ & $3-3$ & 33.3 & $\left(\begin{array}{l}19.6 \\
23.6\end{array}\right.$ \\
4.1 & 55.9 & $9-9$ & $3-4$ & 34.0 & $\left(\begin{array}{l}16.7 \\
18.8\end{array}\right.$ \\
\hline
\end{tabular}

* Contracted specimen. ** As percent of fin length.

The ventral transverse muscles are found throughout the whole trunk. Six to seven longitudinal muscle bands are defined on each half of the dorsal side of the tail segment. Short intestinal diverticula are defined distinctly at 
the beginning of the intestine. The ovary just falls short of the ventral ganglion and contains several mature eggs. No cement gland is found the female genital opening. Only a single expanded seminal vesicle was found on the $4.1 \mathrm{~mm}$ long specimen. The sperm sac itself is elongate ellipsoidal in shape. The vesicle seems to rupture along the anterior half of the lateral side, and there is found a forward thickening at the posterior end of this rupture line which might grow up to be "a sharply pointed prominence protruded obliquely forward from the posterolateral corner" as in the Japanese specimens.

Remraks: Among the described species of Spadella, S. moretonensis JoHnston and TAYLOR has the lateral fin extending onto the posterior trunk and several species of schizoptera group are provided with such a fin or with posterior fin beginning at the trunk-tail septum and anterior fin much shorter than the posterior. Species of schizoptera-group are easily distinguishable by their characteristic adherent organ, while $S$. moretonensis resembles rather closely the present species in the appearance of the lateral fin, the rough outline of the corona ciliata, the armature formula, and in that it is devoid of any com. plete palm-shaped adherent organ. However, this species is described to bear on the right ventral side of the tail segment two small club-shaped protuberances covered with minute papillae and the posterior end of the lateral fin continues to the tail fin going round the small seminal vesicle. It is possible that this might rather be a form of schizoptera-group bearing no complete adhesive organs but rudimentary ones. Moreover, it is described that S. moretonensis is provided with ventral transverse muscles in the tail segment as well as in the trunk.

Throughout the present Malay and the Japanese specimens, the armature formula is to be extended to $8-9 \frac{2-4}{0-1}$ in $2.5-4.1 \mathrm{~mm}$ individuals, and the length of the tail segment varies from 48.6 to 55.9 precent of the total body length.

\section{REFERENCES}

ConANT, F. S. (1895): Description of two new chaetognaths (Spadella schizoptera and Sagitta hispida). Johns Hopkins Univ. Circulars, 14 (119).

Johnston, T. H. and B. B. TAylor (1919): Notes on Australian Chaetognatha. Proc. Roy. Soc. Queensland, 31 (3).

MAwson, P. M. (1944): Some species of the chaetognath genus Spadella from New South Wales. Trans. Roy. Soc. South Australia, 68 (2).

OWRE, H. B. (1963): The genus Spadella (Chaetognatha) in the western North Atlantic Occan, with descriptions of two new species. Bull. Mar. Sci. Gulf and Caribbean, 13 (3).

RitTer-ZÁHony, R. (1911) : Revision der Chätognathen. Deutsch. Suidpol.-Exped. 1901-03, 13 (Zool. 5) (1).

TokIokA, T. (1951): Pelagic tunicates and chaetognaths collected during the cruises to the New Yamato Bank in the Sea of Japan. Publ. Seto Mar. Biol. Lab., 2 (1).

Yosir, N. and T. TokiokA (1939): Notes on Japanese Spadella (Chaetognatha). Annot. Zool, Japon., 18 (4). 


\section{EXPLANATION OF PLATE V}

A. $4.1 \mathrm{~mm}$ long individual, dorsal. $\times 47$

B. Corona ciliata of the same specimen. $\quad \times 73$

C. Posterior portion of tail segment, dorsal. $\quad \times 73$

The left vesicle is near maturity, while the right is shortly after the rupture. thi.--thickening corresponding to the sharply pointed prominence found in Japanese specimens. 
Publ. Seto Mar. Biol. Lab., XII, 2 (1964) PlATE V
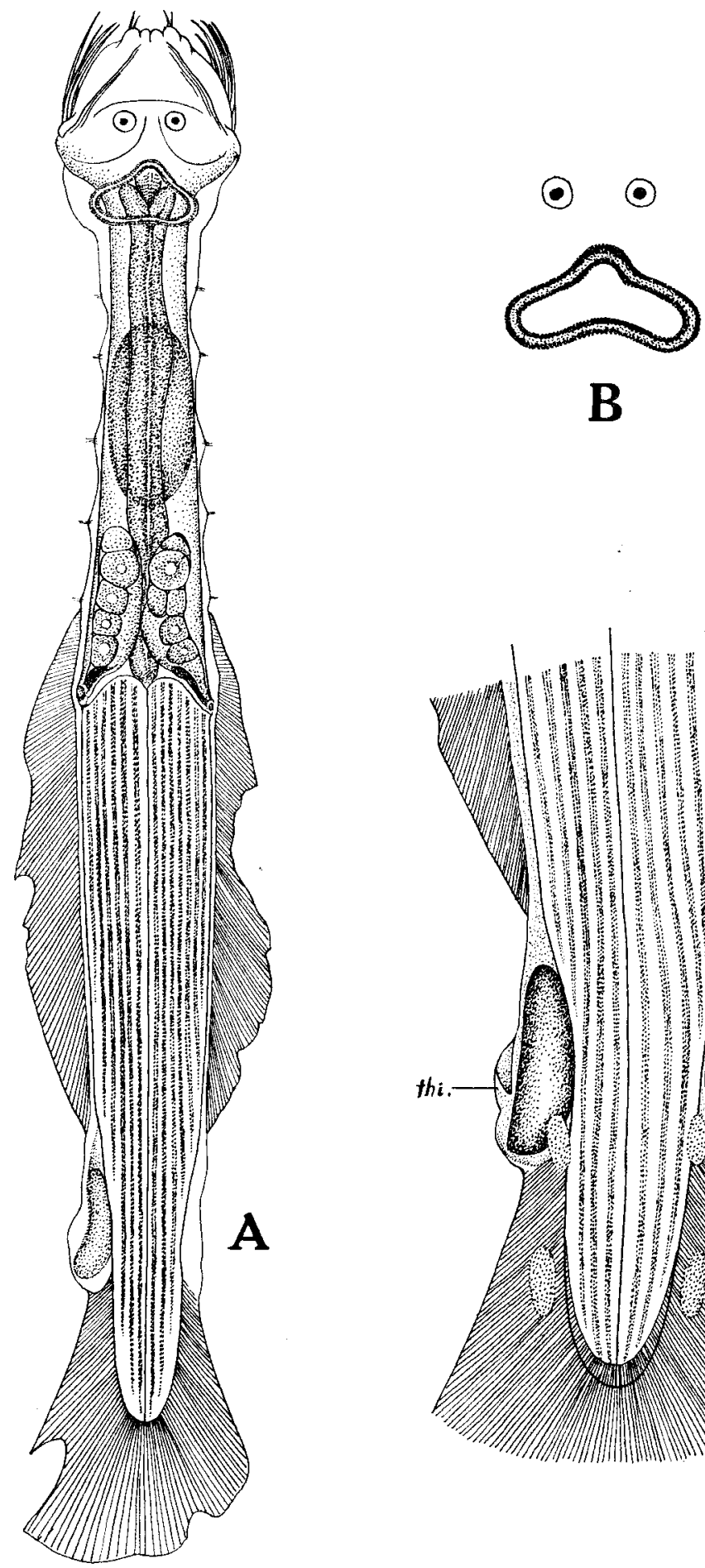

T. Tokioka and D. Pathansali: Spadella angulata. 